\title{
KOMPETENSI KOMUNIKASI PENDAMPING DAN KEPUASAN PETANI DALAM PELAKSANAAN PROGRAM SIMANTRI (Communication Competence of Facilitator and Farmer Satisfaction on Simantri Programme) \\ Kadek Diah Pradnyani', Djuara P Lubis², Eko Sri Mulyani ${ }^{3}$
}

\author{
${ }^{1}$ Asisten Peneliti di Centras LPPM-IPB
}

${ }^{2}$ Staf Pengajar Departemen Sains Komunikasi dan Pengembangan Masyarakat, FEMA IPB

${ }^{3}$ Kepala Bidang KSPHP Pusat Penelitian dan Pengembangan Tanaman Pangan, Badan Penelitian dan Pengembangan Pertanian Kementrian Pertanian

$$
\text { e-mail: pradnyanidiah28@gmail.com }
$$

Naskah diterima: 29 Januari 2016; Direvisi: 27 April 2016; Disetujui: 06 Juni 2016

\begin{abstract}
This study aims to (1) describe communication competence of facilitator on Simantri programme, (2) describe the level of farmer satisfaction toward facilitator, (3) analyze the relationship of internal and external factors of facilitator with their communication competence, and (4) analyze the relationship of facilitator communication competence with farmer satisfaction. It was a survey study and the unit of analysis was the outsourcing facilitator of Simantri programme. The respondents were 30 facilitators and 150 farmers of Simantri in Klungkung and Jembrana Regency. The methods of collecting data were questionnaire and interview. The data analyzing technique used descriptive analyzing, Rank Spearman, and Mann-Whitney assisted by SPSS 22.0. The result indicated (1) the level of communication competence of facilitators in Klungkung and Jembrana are generally high (based on self-report and receiver-report); (2) the level of farmers satisfaction are high; (3) internal factor of facilitator has significant correlations with their communication competence and external factor of facilitator (the number of training) has significant correlations with their communication competence; (4) almost all indicators on facilitator communication competence has significant correlations with farmer satisfaction.
\end{abstract}

Keywords: communication competence, farmer satisfaction, Simantri programme

\section{PENDAHULUAN}

Sistem Pertanian Terintegrasi (Simantri) merupakan salah satu program pembangunan Pemerintah Provinsi Bali sejak tahun 2009 yang memanfaatkan inovasi teknologi pertanian tanpa limbah dalam upaya peningkatan kesejahteraan masyarakat sesuai dengan kondisi sosial ekonomi dan lingkungan setempat (BPTP Prov Bali 2011). Simantri menjadi program unggulan Pemerintah Provinsi Bali dengan target 1000 unit Simantri di tahun 2018 (Anugrah et al. 2014). Hingga tahun 2014 sudah tersebar 502 unit Simantri di seluruh kabupaten/kota di Provinsi Bali (BPTP Prov Bali 2014).
Hasil evaluasi BPTP Provinsi Bali terhadap 419 unit Simantri tahun 20092013 menunjukkan bahwa 63 unit Simantri belum melaksanakan kegiatan secara optimal (BPTP Prov Bali 2014). Hasil penelitian Suardi (2015) menyatakan perilaku petani dalam aspek pengetahuan dan sikap terhadap Simantri tergolong kategori baik, namun masih kurang pada aspek tindakan atau pelaksanaan program. Keberhasilan program akan sulit tercapai jika pelaku program tidak melaksanakan kegiatan program.

Kondisi tersebut bisa disebabkan oleh kurang efektifnya komunikasi program Simantri. Salah satu hal yang dapat mendukung efektivitas komunik asi adalah kegiatan pendampingan yang 
optimal oleh pendamping Simantri. Setiap unit Simantri dibantu oleh seorang pendamping yang secara umum bertugas mendampingi petani penerima bantuan Simantri dalam membuat keputusan dan pengelolaan kegiatan Simantri, memperkenalkan teknis kegiatan integrasi yang sesuai kondisi lokasi, memotivasi kelompok, fasilitator informasi, membantu kegiatan administrasi, serta berkoordinasi dengan petugas lain di tingkat desa hingga provinsi (Distan Prov Bali 2013). Dinas Pertanian Tanaman Pangan Provinsi Bali (leading sector program) merekrut tenaga pendamping outsourcing sebanyak 200 orang pada tahun 2012 dan 2014 untuk menggantikan pendamping insourcing. Pendamping outsourcing sebagian besar belum memiliki pengalaman kerja dan rata-rata mendampingi tiga unit Simantri. Leading sector program Simantri mengadakan pertemuan dengan pendamping di Sekretariat Simantri setiap minggunya sebagai bentuk koordinasi dan monitoring. Pertemuan tersebut diketahui belum berlangsung efektif karena pendamping masih ragu menyampaikan permasalahan yang dihadapi, jumlah pendamping yang hadir tidak selalu lengkap, serta komunikasi dalam pertemuan tersebut masih bersifat satu arah.

Mangkuprawira (2010) menyatakan bahwa kegiatan pendampingan diperlukan karena adanya kesenjangan pemahaman antara pihak yang memberikan bantuan dengan penerima bantuan. Seorang pendamping harus mampu menjadi perencana, pembimbing, pemberi informasi, motivator, penghubung, fasilitator, dan juga evaluator (Mangkuprawira 2010). Susanto (2010) menyatakan bahwa sumberdaya manusia pendamping yang berkualitas dan handal adalah pendamping yang memiliki kompetensi yang tinggi. Kegiatan pendampingan dalam program Simantri sangat memerlukan pendamping yang memiliki kompetensi komunikasi yang baik agar proses komunikasi antara pendamping dengan leading sector dan petani menjadi efektif. Seseorang yang memiliki kompetensi komunikasi berarti mampu berkomunikasi secara efektif dan memanfaatkan keahlian yang dimiliki sehingga tujuan yang diharapkan dapat tercapai (Jeffrey \& Brunton 2010). Kompetensi komunikasi memerlukan kognitif dan interaksi keterampilan, motivasi untuk melakukan kontrol pribadi, memiliki rasa empati, kemampuan untuk menyesuaikan diri, dan memengaruhi lingkungan (Heath \& Bryant 2000, Payne 2005).

Menilai kepuasan petani dapat menjadi sebuah ukuran keberhasilan pendamping menyampaikan pesan dengan tepat dan efektif sesuai dengan tujuan. Hal ini sesuai dengan pernyataan Berlo (1960) bahwa kritik terhadap komunikator dapat dilihat dari tindakan penerima pesan. Petani adalah penerima pesan dari pendamping, sehingga tindakan petani dapat dijadikan kriteria bahwa pendamping adalah komunikator yang kompeten. Tingkat kepuasan petani dapat menjadi salah satu ukurannya. Pendamping Simantri yang memiliki kompetensi komunikasi yang baik akan berusaha mencapai komunikasi yang efektif sehingga dapat membantu petani dalam pelaksanaan program Simantri. Pelaksanaan kegiatan yang baik tentu akan mewujudkan tujuan program Simantri.

Penelitian ini bertujuan untuk (1) mendeskripsikan kompetensi komunikasi pendamping program Simantri, mendeskripsikan tingkat kepuasan petani terhadap pendamping, (3) menganalisis hubungan faktor internal dan eksternal pendamping dengan kompetensi komunikasi pendamping, dan (4) menganalisis hubungan kompetensi komunikasi pendamping dengan kepuasan petani terhadap pendamping. 


\section{KERANGKA BERPIKIR}

Sistem $\begin{gathered}\text { Pertanian } \\ \text { merupakan }\end{gathered} \begin{array}{r}\text { Terintegrasi } \\ \text { program } \\ \text { (Simantri) }\end{array}$
pembangunan $\begin{gathered}\text { unggulan } \\ \text { Pemerintah }\end{gathered}$
Provinsi Bali sejak tahun 2009 yang
memanfaatkan inovasi teknologi pertanian
tanpa limbah dalam upaya peningkatan
kesejahteraan masyarakat (BPTP Prov Bali
2011). Petani penerima bantuan Simantri
dibantu oleh seorang pendamping yang
secara umum bertugas mendampingi
petani dalam pengelolaan kegiatan,
memotivasi kelompok, fasilitator
informasi, membantu administrasi, serta
berkoordinasi dengan petugas lain di
tingkat desa hingga provinsi (Distan Prov
Bali 2013).

Kegiatan komunikasi pembangunan dalam program Simantri sangat memerlukan petugas pendamping yang memiliki kompetensi komunikasi yang baik dalam melaksanakan kegiatan komunikasi pembangunan yang direncanakan, sehingga mampu meningkatkan kepuasan petani pelaksana program Simantri. Kompetensi komunikasi petugas pendamping dapat dilihat pada 11 indikator, sedangkan kepuasan petani terhadap pendamping dapat diukur berdasarkan lima indikator. Kompetensi komunikasi petugas pendamping diduga berhubungan dengan faktor internal dan eksternal petugas pendamping tersebut. Faktor internal tersebut meliputi umur, masa kerja, tingkat pendidikan formal, tingkat kekosmopolitan, dan motivasi. Faktor eksternal meliputi jumlah pelatihan dan pengalaman organisasi.

Penelitian ini melibatkan pendamping Simantri dan petani pelaksana Simantri sebagai responden. Data variabel faktor internal dan eksternal diisi oleh pendamping. Variabel kompetensi komunikasi dinilai oleh pendamping dan petani. Petani juga sebagai responden dalam melengkapi data kepuasan petani terhadap pendamping. Kerangka pemikiran penelitian ini dapat dilihat pada Gambar 1.

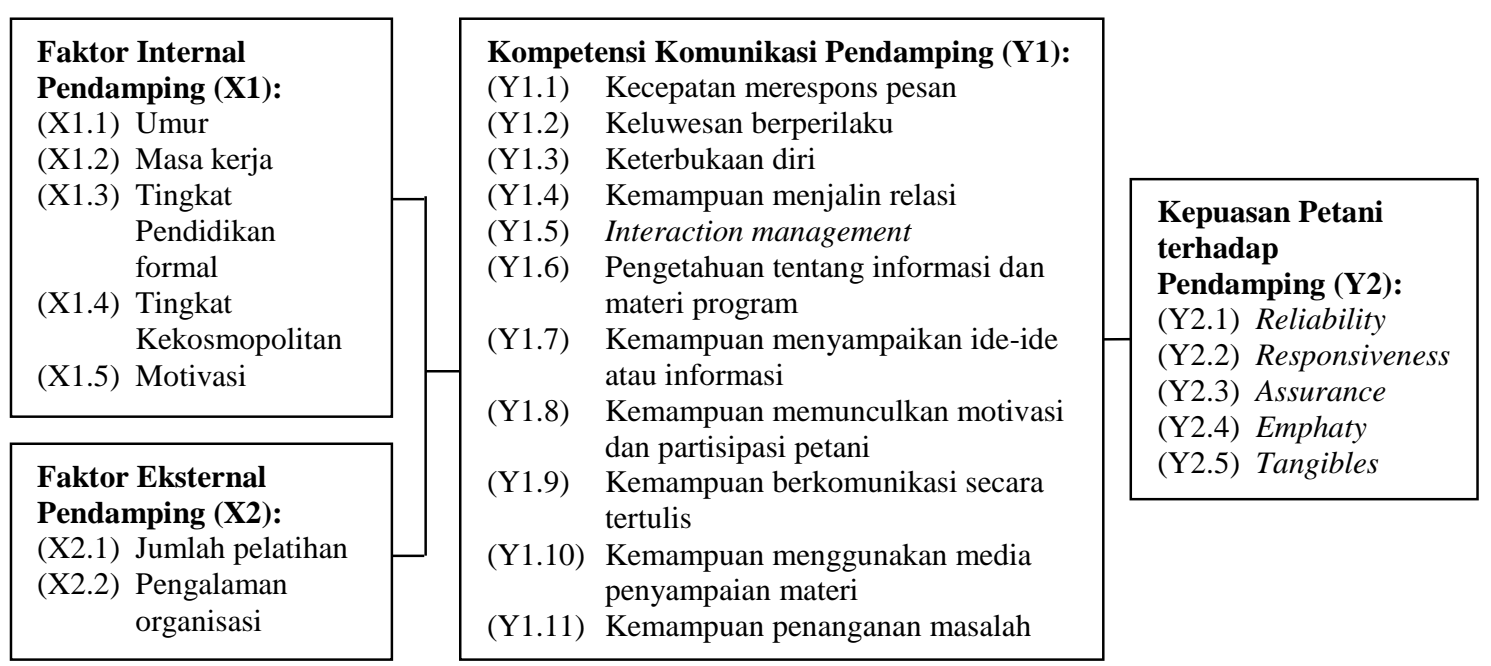

Gambar 1. Kerangka berpikir kompetensi komunikasi petugas pendamping dan kepuasan petani dalam pelaksanaan program simantri

METODE PENELITIAN
Desain penelitian ini adalah penelitian survei dengan pendamping outsourcing Simantri sebagai unit analisis 
penelitian. Variabel bebas penelitian adalah faktor internal pendamping (X1) dan faktor eksternal pendamping (X2). Kompetensi komunikasi pendamping (Y1) merupakan variabel antara, serta kepuasan petani terhadap pendamping (Y2) merupakan variabel terikat. Pengumpulan data dilakukan di Kabupaten Klungkung dan Jembrana Provinsi Bali yang berlangsung pada bulan Maret-Mei 2016. Populasi dalam penelitian ini adalah seluruh petugas pendamping outsourcing pada program Simantri di Kabupaten Klungkung dan Kabupaten Jembrana yang direkrut pada tahun 2012-2014. Jumlah reponden pendamping sebanyak 30 orang berdasarkan perhitungan dengan rumus Slovin. Penetapan responden pendamping menggunakan teknik simple random sampling. Seorang pendamping akan dinilai pula oleh 5 orang petani dampingan mereka, sehingga penilaian terhadap 30 responden pendamping dilakukan oleh 150 responden dari petani.

Data primer dalam penelitian ini diambil dari variabel yang diteliti dan diperoleh langsung dari responden dengan menggunakan kuesioner serta hasil wawancara bertahap dengan atasan pendamping, yakni Pejabat Pelaksana Teknis Kegiatan Pemantapan dan Pengembangan Simantri dan Tim Teknis
Simantri Tingkat Kabupaten. Kuesioner untuk variabel $\mathrm{X} 1, \mathrm{X} 2$, dan $\mathrm{Y} 1$ akan diberikan kepada pendamping yang terpilih sebagai responden, sedangkan kuesioner terkait penilaian variabel Y1 dan Y2 akan diberikan kepada petani yang terpilih sebagai responden. Data sekunder yang dikumpulkan dalam penelitian ini adalah Petunjuk Pelaksanaan Petugas Pendampingan, Petunjuk Teknis Program Simantri, serta Data Penerima Bantuan Simantri tahun 2009-2014. Analisis data yang digunakan adalah (1) analisis statistik deskriptif, (2) analisis korelasi rank Spearman, dan (3) analisis komparatif Mann-Whitney.

\section{DESKRIPSI UMUM}

\section{Deskripsi Faktor Internal Pendamping}

Faktor internal pendamping merupakan ciri-ciri yang melekat pada diri pendamping yang membedakan dirinya dengan pendamping yang lain. Deskripsi faktor internal dari 30 orang pendamping yang terpilih menjadi responden disajikan pada Tabel 1. Pendamping Simantri berusia antara 24 sampai 54 tahun. Pendamping lebih dominan berusia muda (24-33 tahun).

Tabel 1 Faktor internal pendamping simantri kabupaten klungkung dan kabupaten jembrana

\begin{tabular}{|c|c|c|c|c|c|c|c|}
\hline \multirow[b]{2}{*}{ Faktor internal (X1) } & \multicolumn{3}{|c|}{ Kabupaten klungkung } & \multicolumn{3}{|c|}{ Kabupaten jembrana } & \multirow{2}{*}{$\begin{array}{c}\text { A. Sig. } \\
\text { (2-tailed) }\end{array}$} \\
\hline & $\begin{array}{l}\text { Jumlah } \\
\text { (orang) }\end{array}$ & $(\%)$ & $\begin{array}{c}\text { Mean } \\
\text { rank }\end{array}$ & $\begin{array}{l}\text { Jumlah } \\
\text { (orang) }\end{array}$ & $(\%)$ & $\begin{array}{c}\text { Mean } \\
\text { rank }\end{array}$ & \\
\hline \multicolumn{8}{|l|}{ Umur (tahun) } \\
\hline Muda (24-33) & 10 & 66.7 & & 8 & 53.3 & & \\
\hline Dewasa (34-43) & 4 & 26.7 & 13.77 & 4 & 26.7 & 17.23 & 0.280 \\
\hline Tua (44-54) & 1 & 6.7 & & 3 & 20.0 & & \\
\hline \multicolumn{8}{|l|}{ Masa kerja (bulan) } \\
\hline Baru (16-28) & 10 & 66.7 & & 8 & 53.3 & & \\
\hline Sedang (29-41) & 0 & 0.0 & 16.77 & 2 & 13.3 & 14.23 & 0.410 \\
\hline Lama (42-58) & 5 & 33.3 & & 5 & 33.3 & & \\
\hline \multicolumn{8}{|c|}{ Tingkat pendidikan formal } \\
\hline $\mathrm{S} 1$ & 14 & 93.3 & 15.50 & 14 & 93.3 & 15.50 & 1.000 \\
\hline S2 & 1 & 6.7 & & 1 & 6.7 & & \\
\hline \multicolumn{8}{|c|}{ Tingkat kekosmopolitan } \\
\hline Rendah (10-19) & 3 & 20.0 & & 3 & 20.0 & & \\
\hline Sedang (20-29) & 12 & 80.0 & 16.63 & 12 & 80.0 & 14.37 & 0.478 \\
\hline
\end{tabular}




\begin{tabular}{|c|c|c|c|c|c|c|c|}
\hline Tinggi (30-40) & 0 & 0.0 & & 0 & 0.0 & & \\
\hline \multicolumn{8}{|l|}{ Tingkat motivasi } \\
\hline Rendah (14-32) & 0 & 0.0 & & 0 & 0.0 & & \\
\hline Sedang (33-51) & 8 & 53.3 & 15.53 & 6 & 40.0 & 15.47 & 0.983 \\
\hline Tinggi (52-70) & 7 & 46.7 & & 9 & 60.0 & & \\
\hline
\end{tabular}

Jumlah pendamping berusia muda di Kabupaten Klungkung adalah 10 orang (66.7 persen) dan di Kabupaten Jembrana 8 orang (53.3 persen). Pendamping yang termasuk dalam kategori tua berjumlah paling sedikit yakni 1 orang (6.7 persen) di Kabupaten Klungkung dan 3 orang (20 persen) di Kabupaten Jembrana.

Masa kerja pendamping paling banyak masih tergolong baru, yakni 10 orang pendamping Klungkung (66.7 persen) dan 8 orang pendamping Jembrana (53.3 persen). Masa kerja yang tergolong baru adalah pendamping dengan masa kerja antara 1 tahun 4 bulan sampai 2 tahun 4 bulan.

Seorang pendamping Simantri minimal harus memiliki pendidikan S1. Hal ini sesuai dengan hasil penelitian bahwa 93.3 persen responden atau 28 orang pendamping memiliki tingkat pendidikan S1, yakni 14 orang di masingmasing kabupaten. Dua orang pendamping sudah menempuh pendidikan S2, masingmasing 1 orang di setiap kabupaten.

Pendamping Klungkung dominan berasal dari latar belakang ilmu agribisnis. Hal tersebut merupakan peluang pendamping Klungkung untuk mengembangkan pemasaran hasil produk Simantri di Kabupaten Klungkung. Pendamping Jembrana berasal dari latar belakang ilmu yang beragam, seperti agribisnis, agroekoteknologi, teknologi pertanian, peternakan, dan kedokteran hewan. Hal tersebut menjadi peluang bagi pendamping Jembrana untuk saling berbagi ilmu pengetahuan untuk optimalisasi kegiatan Simantri.

Tingkat kekosmopolitan dilihat dari seberapa sering seorang pendamping mencari informasi ke beberapa sumber informasi. Pendamping Klungkung dan
Jembrana paling banyak memiliki tingkat kekosmopolitan pada kategori sedang, yakni masing-masing sejumlah 12 orang (80 persen). Sumber informasi yang paling sering didatangi oleh pendamping, baik pendamping Klungkung maupun Jembrana adalah sesama pendamping.

Pendamping Klungkung lebih sering mencari informasi ke sesama pendamping, petani, petugas di Sekretariat Simantri, dan mengakses informasi melalui internet. Pendamping Jembrana lebih sering mencari informasi ke sesama pendamping, petugas di Sekretariat Simantri, petani, internet, dan koran. Seringnya pendamping yang mencari informasi ke sesama pendamping menandakan bahwa ada upaya saling membantu antar sesama pendamping dalam memberikan masukan dan saran untuk perkembangan Simantri dampingan mereka. Memiliki posisi yang sama sebagai pendamping membuat mereka lebih nyaman untuk bertanya dan mendapatkan informasi. Media radio dan televisi termasuk yang paling jarang diakses oleh pendamping.

Tingkat motivasi pendamping Kabupaten Klungkung dominan tergolong sedang (53.3 persen atau 8 orang) dan sisanya tergolong tinggi (46.7 persen). Tingkat motivasi pendamping Kabupaten Jembrana tergolong tinggi, yakni sebesar 60 persen (9 orang) dan tergolong sedang sebanyak 40 persen ( 6 orang). Pendamping Klungkung lebih banyak termotivasi untuk berpretasi. Maksud dari berprestasi adalah pendamping mampu membawa kelompok yang mereka dampingi melakukan kegiatan program serta mampu mengarahkan kelompok menjadi semakin mandiri. Kemauan dan semangat kelompok adalah prestasi bagi seorang pendamping. Pendamping Jembrana paling 
banyak termotivasi untuk meningkatkan pengetahuan dalam bekerja. Pekerjaan menjadi pendamping Simantri memang dapat memberikan ilmu pengetahuan dari berbagai bidang, seperti pemeliharaan dan kesehatan ternak, teknologi pengolahan kotoran ternak menjadi pupuk dan biogas, budidaya tanaman, serta pemasaran.

Nilai signifikansi hasil analisis komparatif indikator pada variabel faktor internal antara pendamping Kabupaten Jembrana dan Klungkung lebih besar dari alfa 10 persen yang dapat disimpulkan Tabel 2 Faktor eksternal pendamping simantri kabupaten klungkung dan kabupaten jembrana

\begin{tabular}{|c|c|c|c|c|c|c|c|}
\hline \multirow{2}{*}{$\begin{array}{l}\text { Faktor } \\
\text { Eksternal (X2) }\end{array}$} & \multicolumn{3}{|c|}{ Kabupaten Klungkung } & \multicolumn{3}{|c|}{ Kabupaten Jembrana } & \multirow{2}{*}{$\begin{array}{c}\text { A. Sig. } \\
\text { (2-tailed) }\end{array}$} \\
\hline & $\begin{array}{l}\text { Jumlah } \\
\text { (orang) }\end{array}$ & $\begin{array}{c}\text { Persentase } \\
(\%)\end{array}$ & $\begin{array}{l}\text { Mean } \\
\text { Rank }\end{array}$ & $\begin{array}{l}\text { Jumlah } \\
\text { (orang) }\end{array}$ & $\begin{array}{c}\text { Persentase } \\
(\%)\end{array}$ & $\begin{array}{l}\text { Mean } \\
\text { Rank }\end{array}$ & \\
\hline \multicolumn{8}{|l|}{ Jumlah Pelatihan } \\
\hline Rendah & 10 & 66.7 & \multirow{3}{*}{14.67} & 5 & 33.3 & \multirow{3}{*}{16.33} & \multirow{3}{*}{0.585} \\
\hline Sedang & 3 & 20.0 & & 10 & 66.7 & & \\
\hline Tinggi & 2 & 13.3 & & 0 & 0.0 & & \\
\hline \multicolumn{8}{|l|}{ Pengalaman } \\
\hline \multicolumn{8}{|l|}{ Organisasi } \\
\hline Rendah & 11 & 73.3 & \multirow{3}{*}{13.00} & 10 & 66.7 & \multirow{3}{*}{13.00} & \multirow{3}{*}{1.000} \\
\hline Sedang & 3 & 20.0 & & 5 & 33.3 & & \\
\hline Tinggi & 1 & 6.7 & & 0 & 0.0 & & \\
\hline
\end{tabular}

Pendamping Klungkung dominan masih tergolong rendah dalam mengikuti pelatihan (1-2 pelatihan), yakni sejumlah 10 orang (66.7 persen). Tiga orang pendamping memiliki jumlah pelatihan tergolong sedang (3-4 pelatihan), serta dua orang pendamping memiliki jumlah pelatihan paling tinggi (5-7 pelatihan). Pendamping Jembrana dominan memiliki jumlah pelatihan yang tergolong sedang (10 orang atau 66.7 persen). Lima orang pendamping (33.3 persen) masuk dalam kategori rendah, dan tidak ada yang memiliki jumlah pelatihan tinggi.

Pengalaman organisasi diukur berdasarkan jumlah organisasi yang pernah diikuti pendamping, baik organisasi kemahasiswaan maupun organisasi kemasyarakatan. Sebagian besar pendamping Simantri memiliki pengalaman organisasi yang rendah, baik pendamping Klungkung (73.3 persen) bahwa tidak ada perbedaan signifikan faktor internal antara pendamping Kabupaten Jembrana dan Klungkung.

\section{Deskripsi Faktor Eksternal Pendamping}

Faktor eksternal pendamping adalah ciri-ciri yang berasal dari luar individu pendamping. Faktor eksternal pendamping terdiri dari dua indikator, yakni jumlah pelatihan dan pengalaman organisasi. Deskripsi faktor eksternal pendamping disajikan pada Tabel 2. 
KOMPETENSI KOMUNIKASI

\section{PENDAMPING DAN}

HUBUNGANNYA DENGAN FAKTOR INTERNAL DAN EKSTERNAL

\section{PENDAMPING}

\section{Kompetensi Komunikasi Pendamping}

Kompetensi

komunikasi

pendamping diukur berdasarkan hasil penilaian dari pendamping itu sendiri dan petani yang menjadi kelompok dampingan pendamping. Tabel 3 menyajikan kompetensi komunikasi pendamping Kabupaten Klungkung dan Kabupaten Jembrana berdasarkan penilaian sendiri dan penilaian petani.
Kompetensi

komunikasi pendamping Simantri secara umum tergolong tinggi, baik pendamping Klungkung maupun pendamping Jembrana berdasarkan penilaian sendiri dan penilaian petani. Hasil penilaian berbeda terlihat pada penilaian petani terhadap pendamping Klungkung. Penilaian berbeda muncul pada tiga indikator, yakni kemampuan menjalin relasi, kemampuan komunikasi tertulis, dan kemampuan penggunaan media penyampaian materi yang dominan berada pada kategori sedang.

Tabel 3 Kompetensi komunikasi pendamping simantri kabupaten klungkung dan kabupaten jembrana berdasarkan penilaian sendiri dan penilaian petani

\begin{tabular}{|c|c|c|c|c|}
\hline \multirow[b]{2}{*}{$\begin{array}{l}\text { Kompetensi komunikasi } \\
\text { pendamping (Y1) }\end{array}$} & \multicolumn{2}{|c|}{ Kabupaten klungkung } & \multicolumn{2}{|c|}{ Kabupaten jembrana } \\
\hline & $\begin{array}{c}\text { Penilaian } \\
\text { sendiri }(\%)\end{array}$ & $\begin{array}{l}\text { Penilaian } \\
\text { petani }(\%)\end{array}$ & $\begin{array}{c}\text { Penilaian } \\
\text { sendiri }(\%)\end{array}$ & $\begin{array}{l}\text { Penilaian } \\
\text { petani }(\%)\end{array}$ \\
\hline \multicolumn{5}{|c|}{ Kecepatan merespons pesan } \\
\hline Rendah & 0.0 & 0.0 & 6.7 & 0.0 \\
\hline Sedang & 0.0 & 20.0 & 0.0 & 6.7 \\
\hline Tinggi & 100.0 & 80.0 & 93.3 & 93.3 \\
\hline \multicolumn{5}{|l|}{ Keluwesan berperilaku } \\
\hline Rendah & 0.0 & 0.0 & 0.0 & 0.0 \\
\hline Sedang & 0.0 & 6.7 & 0.0 & 0.0 \\
\hline Tinggi & 100.0 & 93.3 & 100.0 & 100.0 \\
\hline \multicolumn{5}{|l|}{ Keterbukaan diri } \\
\hline Rendah & 0.0 & 0.0 & 0.0 & 0.0 \\
\hline Sedang & 0.0 & 13.3 & 0.0 & 0.0 \\
\hline Tinggi & 100.0 & 86.7 & 100.0 & 100.0 \\
\hline \multicolumn{5}{|l|}{ Kemampuan menjalin relasi } \\
\hline Rendah & 0.0 & 0.0 & 0.0 & 0.0 \\
\hline Sedang & 40.0 & 60.0 & 20.0 & 26.7 \\
\hline Tinggi & 60.0 & 40.0 & 80.0 & 73.3 \\
\hline \multicolumn{5}{|l|}{ Interaction management } \\
\hline Rendah & 0.0 & 0.0 & 0.0 & 0.0 \\
\hline Sedang & 13.3 & 20.0 & 13.3 & 0.0 \\
\hline Tinggi & 86.7 & 80.0 & 86.7 & 100.0 \\
\hline \multicolumn{5}{|c|}{ Pengetahuan tentang program } \\
\hline Rendah & 0.0 & 0.0 & 0.0 & 0.0 \\
\hline Sedang & 13.3 & 20.0 & 26.7 & 0.0 \\
\hline Tinggi & 86.7 & 80.0 & 73.3 & 100.0 \\
\hline \multicolumn{5}{|l|}{ Penyampaian pesan } \\
\hline Rendah & 0.0 & 0.0 & 0.0 & 0.0 \\
\hline Sedang & 13.3 & 13.3 & 6.7 & 0.0 \\
\hline Tinggi & 86.7 & 86.7 & 93.3 & 100.0 \\
\hline \multicolumn{5}{|l|}{ Kemampuan memotivasi } \\
\hline Rendah & 0.0 & 0.0 & 0.0 & 0.0 \\
\hline Sedang & 26.7 & 40.0 & 33.3 & 0.0 \\
\hline Tinggi & 73.3 & 60.0 & 66.7 & 100.0 \\
\hline \multicolumn{5}{|l|}{ Komunikasi tertulis } \\
\hline Rendah & 0.0 & 0.0 & 0.0 & 0.0 \\
\hline Sedang & 20.0 & 86.7 & 13.3 & 53.3 \\
\hline Tinggi & 80.0 & 13.3 & 86.7 & 46.7 \\
\hline
\end{tabular}




\begin{tabular}{lrrrr} 
Rendah & 20.0 & 13.3 & 13.3 & 0.0 \\
Sedang & 6.7 & 53.3 & 6.7 & 46.7 \\
Tinggi & 73.3 & 33.3 & 80.0 & 53.3 \\
\hline Penanganan masalah & & & & \\
Rendah & 13.3 & 0.0 & 0.0 & 0.0 \\
Sedang & 33.3 & 40.0 & 13.3 & 13.3 \\
Tinggi & 53.3 & 60.0 & 86.7 & 86.7 \\
\hline
\end{tabular}

Kemampuan menjalin relasi pendamping Klungkung hasil penilaian petani tergolong sedang karena adanya pertukaran pendamping yang mendampingi kelompok petani di Klungkung, sehingga ada kelompok yang baru mengenal pendamping selama 2 bulan. Penilaian juga dilihat dari frekuensi pendamping menghubungi petani melalui telepon atau Short Message Service (SMS). Tidak semua anggota pernah dihubungi oleh pendamping melalui telepon ataupun SMS. Pendamping lebih banyak berkomunikasi melalui telepon atau SMS dengan ketua dan/atau pengurus kelompok. Pendamping belum melakukan komunikasi melalui telepon atau SMS untuk berbicara hal di luar Simantri (menjalin kedekatan personal).

Komunikasi melalui SMS tersebut juga memengaruhi penilaian petani pada indikator kemampuan berkomunikasi tertulis yang dilihat dari penggunaan bahasa pendamping dalam SMS yang dikirim kepada petani. Nilai pada indikator tersebut tergolong dalam kategori sedang. Banyak petani yang ragu untuk memberikan penilaian karena sebagian besar petani belum pernah mendapatkan SMS dari pendamping. Hal demikian juga terjadi pada penilaian petani di Kabupaten Jembrana.

Kemampuan penggunaan media diukur berdasarkan kemampuan pendamping menggunakan laptop ketika ada kegiatan di lokasi Simantri. Hasil penilaian mengindikasikan bahwa belum semua pendamping memanfaatkan laptop sebagai media penyampaian informasi. Hal tersebut bisa disebabkan oleh tidak adanya sumber listrik di lokasi Simantri atau berdasarkan pengamatan pendamping yang merasa lebih baik menyampaikan informasi secara langsung kepada petani. Kondisi berbeda ditunjukkan oleh seorang pendamping Klungkung yang tidak hanya menggunakan laptop, tapi sudah pernah memanfaatkan proyektor dan layar untuk menampilkan video kepada petani.

Tabel 4 Hasil analisis komparatif dan mean rank kompetensi komunikasi pendamping simantri kabupaten klungkung dan jembrana

\begin{tabular}{|c|c|c|c|c|c|c|}
\hline \multirow{3}{*}{$\begin{array}{l}\text { Kompetensi komunikasi } \\
\text { pendamping (Y1) }\end{array}$} & \multicolumn{3}{|c|}{ Penilaian sendiri } & \multicolumn{3}{|c|}{ Penilaian petani } \\
\hline & \multicolumn{2}{|c|}{ Mean rank } & \multirow{2}{*}{$\begin{array}{l}\text { A. Sig. } \\
(2- \\
\text { tailed) }\end{array}$} & \multirow{2}{*}{\multicolumn{2}{|c|}{$\frac{\text { Mean rank }}{\text { Klungkung Jembrana }}$}} & \multirow{2}{*}{$\begin{array}{l}\text { A. Sig. (2- } \\
\text { tailed) }\end{array}$} \\
\hline & Klungkung & Jembrana & & & & \\
\hline Kecepatan merespons pesan & 15.47 & 15.53 & 0.972 & 13.80 & 17.20 & 0.274 \\
\hline Keluwesan berperilaku & 15.97 & 15.03 & 0.654 & 11.57 & 19.43 & $0.013^{* *}$ \\
\hline Keterbukaan diri & 15.93 & 15.07 & 0.677 & 12.83 & 18.17 & 0.104 \\
\hline Kemampuan menjalin relasi & 14.70 & 16.30 & 0.588 & 11.37 & 19.63 & $0.010^{* * * *}$ \\
\hline Interaction management & 15.27 & 15.73 & 0.874 & 12.23 & 18.77 & $0.041^{* *}$ \\
\hline Pengetahuan tentang program & 15.50 & 15.50 & 1.000 & 13.17 & 17.83 & 0.143 \\
\hline Penyampaian pesan & 15.60 & 15.40 & 0.942 & 12.43 & 18.57 & $0.055^{*}$ \\
\hline Kemampuan memotivasi & 14.80 & 16.20 & 0.643 & 12.17 & 18.83 & $0.038^{* *}$ \\
\hline Y1.9 Komunikasi tertulis & 15.07 & 15.93 & 0.678 & 13.33 & 17.67 & 0.172 \\
\hline Y1.10 Penggunaan media & 15.77 & 15.23 & 0.837 & 12.93 & 18.07 & 0.107 \\
\hline Y1.11 Penanganan masalah & 12.70 & 18.30 & $0.058^{*}$ & 13.53 & 17.47 & 0.220 \\
\hline
\end{tabular}

Keterangan.: * berhubungan nyata pada nilai signifikansi $<0.10$

*** berhubungan nyata pada nilai signifikansi $<0.05$

**** berhubungan nyata pada nilai signifikansi $<0.01$ 
Tabel 4 memperlihatkan tidak terdapat perbedaan signifikan antara kompetensi komunikasi pendamping Klungkung dengan pendamping Jembrana berdasarkan hasil penilaian sendiri kecuali pada indikator kemampuan penanganan masalah. Terdapat perbedaan signifikan kompetensi komunikasi antara pendamping Klungkung dengan pendamping Jembrana berdasarkan penilaian petani pada indikator keluwesan berperilaku, kemampuan menjalin relasi, interaction management, kemampuan menyampaikan pesan, dan kemampuan memunculkan motivasi dan partisipasi petani. Nilai mean rank atau rata-rata peringkat pendamping Jembrana lebih besar dibandingkan pendamping Klungkung berdasarkan penilaian petani pada lima indikator tersebut. Hal ini menunjukkan petani di Jembrana memberikan nilai yang lebih besar kepada pendampingnya dibandingkan dengan petani di Klungkung.

\section{Hubungan Faktor Internal \\ Pendamping dengan Kompetensi Komunikasi Pendamping}

Analisis korelasi antara faktor internal pendamping dengan kompetensi komunikasi pendamping hasil penilaian sendiri disajikan pada Tabel 5. Umur pendamping berhubungan nyata dengan kemampuan memunculkan motivasi dan partisipasi petani pada taraf nyata 95 persen. Hasil tersebut menunjukkan bahwa semakin bertambah usia seseorang maka kemampuannya dalam memunculkan motivasi dan partisipasi petani semakin meningkat pula. Hal ini sesuai dengan hasil penelitian Marius et al. (2007) yakni usia yang matang disertai dengan pengalaman akan membuat seorang penyuluh berkompeten dalam melaksanakan tugas.

Tabel 5 Hubungan faktor internal pendamping dengan kompetensi komunikasi pendamping simantri (penilaian sendiri)

\begin{tabular}{|c|c|c|c|c|c|c|}
\hline \multirow{2}{*}{\multicolumn{2}{|c|}{$\begin{array}{l}\text { Kompetensi komunikasi pendamping } \\
\text { (Y1) }\end{array}$}} & \multicolumn{5}{|c|}{ Koefisien korelasi (Faktor internal / X1) } \\
\hline & & \multirow{2}{*}{$\begin{array}{c}\text { Umur } \\
-0.003\end{array}$} & \multirow{2}{*}{$\begin{array}{l}\text { Masa } \\
\text { kerja } \\
0.404^{* *}\end{array}$} & \multirow{2}{*}{$\begin{array}{c}\begin{array}{c}\text { Tingkat } \\
\text { pendidikan } \\
\text { formal }\end{array} \\
0.382^{* *}\end{array}$} & \multirow{2}{*}{$\begin{array}{c}\begin{array}{c}\text { Tingkat } \\
\text { kekosmopolitan }\end{array} \\
0.311^{*}\end{array}$} & \multirow{2}{*}{$\begin{array}{c}\text { Motivasi } \\
0.229\end{array}$} \\
\hline Y1.1 & Kecepatan merespons pesan & & & & & \\
\hline Y1.2 & Keluwesan berperilaku & 0.118 & 0.218 & $0.384^{* * *}$ & 0.115 & 0.200 \\
\hline Y1.3 & Keterbukaan diri & -0.009 & 0.171 & $0.398^{* *}$ & -0.037 & 0.125 \\
\hline Y1.4 & Kemampuan menjalin relasi & -0.038 & -0.247 & $0.496^{* *}$ & -0.062 & 0.252 \\
\hline Y1.5 & Interaction management & 0.211 & 0.153 & $0.390^{* *}$ & 0.022 & 0.212 \\
\hline Y1.6 & Pengetahuan tentang program & 0.214 & 0.150 & 0.167 & 0.208 & 0.251 \\
\hline Y1.7 & Penyampaian pesan & 0.100 & -0.139 & $0.367^{* *}$ & 0.080 & $0.381^{* *}$ \\
\hline Y1.8 & Kemampuan memotivasi & $0.415^{* *}$ & 0.087 & $0.326^{*}$ & 0.201 & $0.382^{* *}$ \\
\hline Y1.9 & Komunikasi tertulis & 0.111 & $-0.363^{* *}$ & 0.193 & -0.264 & 0.132 \\
\hline Y1.10 & Penggunaan media & -0.287 & 0.078 & -0.072 & -0.152 & 0.295 \\
\hline Y1.11 & Penanganan masalah & 0.029 & -0.247 & 0.207 & -0.087 & 0.163 \\
\hline
\end{tabular}

Widodo (2010) menjelaskan bahwa semakin lama masa kerja atau pengalaman seorang penyuluh, maka akan meningkat pula pengembangan profesionalisme seorang penyuluh dan kompetensinya menjadi lebih baik. Hal demikian juga terlihat pada hasil penelitian bahwa masa kerja berhubungan nyata dengan kecepatan merespons pesan pada taraf nyata 95 persen. Pendamping dengan masa kerja lebih lama sudah lebih terbiasa berinteraksi dengan petani dampingan mereka dan sudah lebih memahami bahasa yang disampaikan petani, sehingga lebih cepat merespons perkataan petani.

Tingkat pendidikan formal berhubungan nyata dengan kecepatan merespons pesan, keluwesan berperilaku, 
keterbukaan diri, kemampuan menjalin relasi, interaction management, dan kemampuan menyampaikan ide-ide atau informasi. Pendamping dengan tingkat pendidikan formal yang kentara lebih tinggi adalah dua orang pendamping yang sudah lulus pendidikan S2. Dua pendamping tersebut dipercaya menjadi koordinator Provinsi dan koordinator Kabupaten Jembrana yang menandakan kompetensi komunikasi mereka baik sehingga dipilih menjadi koordinator dan menjadi contoh bagi pendamping lainnya.

Terdapat hubungan nyata dan positif antara tingkat kekosmopolitan dengan kecepatan merespons pesan pada taraf nyata 90 persen. Pendamping yang cepat merespons perkataan dari petani berarti kaya akan informasi-informasi terkait Simantri. Kekosmopolitan akan menumbuhkan kemampuan individu dalam berkomunikasi (Indra 2011) dan berpengaruh langsung terhadap kompetensi individu (Widodo 2010).

Motivasi memiliki hubungan nyata dan positif dengan kemampuan menyampaikan ide-ide atau informasi serta kemampuan memunculkan motivasi dan partisipasi petani pada taraf nyata 95 persen. Pendamping dengan motivasi yang tinggi tentu menginginkan kelompok dampingan yang memiliki motivasi yang tinggi pula. Pendamping akan selalu berusaha meningkatkan motivasi dan partisipasi petani. Salah satu contohnya adalah menyampaikan informasi-informasi teknologi terbaru terkait Simantri pada saat persiapan lomba Simantri.

"Kak pernah diuji waktu lomba [lomba Simantri-red]. Kakak kan awalnya dipilih itu kan mendadak, karena dia [Simantri binaannya-red] baru berjalan setahun ya kan. Sapi pun belum lahir. Akhirnya kakak putar otak, ... Akhirnya dari segi teknologi inovasi kak tambah. Kak buat tabulampot, fermentor sendiri. Nah, di sana guna perannya pendamping... akhirnya menang."

Inovasi yang diperkenalkan pendamping meningkatkan semangat petani untuk memenangkan perlombaan Simantri. Ide-ide dan kreativitas pendamping yang diterapkan petani di kelompok tersebut menjadi nilai tambah saat perlombaan dan memberikan kemenangan kepada mereka.

\section{Hubungan Faktor Eksternal Pendamping dengan Kompetensi Komunikasi Pendamping}

$\begin{array}{ccr}\begin{array}{c}\text { Hubungan } \\ \text { pendamping }\end{array} & \begin{array}{l}\text { faktor } \\ \text { dengan }\end{array} & \begin{array}{r}\text { eksternal } \\ \text { kompetensi }\end{array}\end{array}$ komunikasi pendamping berdasarkan penilaian sendiri disajikan pada Tabel 5. Hasil analisis korelasi menunjukkan bahwa jumlah pelatihan berhubungan dengan kompetensi komunikasi pendamping, yakni pada indikator keluwesan berperilaku, keterbukaan diri, kemampuan menjalin relasi, interaction management, pengetahuan terhadap informasi dan materi program, serta kemampuan menggunakan media penyampaian materi.

Tabel 5 Hubungan faktor eksternal pendamping dengan kompetensi komunikasi pendamping simantri (penilaian sendiri)

\begin{tabular}{llcc}
\hline \multirow{2}{*}{ Kompetensi komunikasi pendamping (Y1) } & \multicolumn{2}{c}{ Koefisien korelasi (Faktor eksternal / X2) } \\
\cline { 3 - 4 } & Jumlah pelatihan & Pengalaman organisasi \\
\hline Y1.1 Kecepatan merespons pesan & 0.097 & 0.238 \\
Y1.2 & Keluwesan berperilaku & $0.523^{* * *}$ & 0.048 \\
Y1.3 & Keterbukaan diri & $0.315^{*}$ & 0.268 \\
Y1.4 & Kemampuan menjalin relasi & $0.358^{*}$ & -0.138 \\
Y1.5 & Interaction management & $0.327^{*}$ & -0.051
\end{tabular}




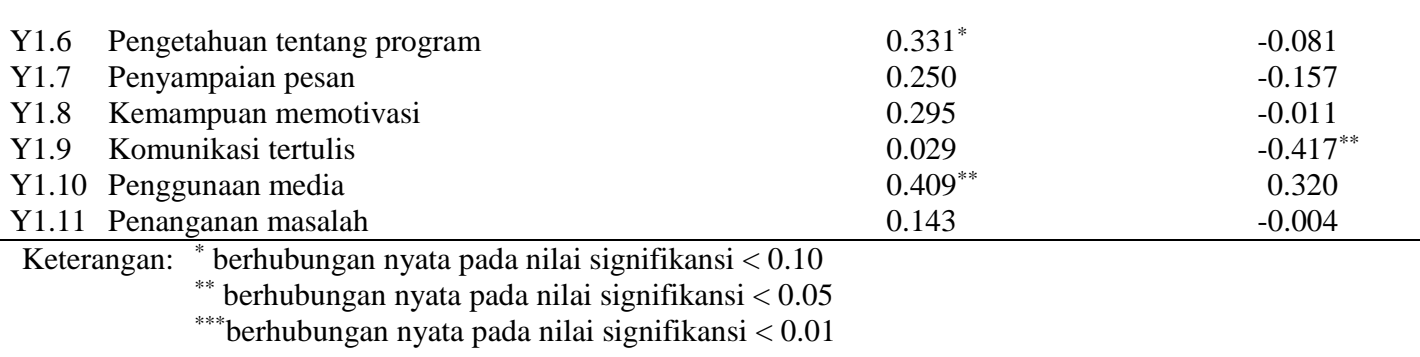

Hal tersebut sesuai dengan hasil penelitian Anwas (2013) dan Widodo (2010) bahwa intensitas pelatihan berpengaruh pada kompetensi penyuluh. Pelatihan yang diikuti pendamping akan meningkatkan kompetensi komunikasi mereka (Susilowati 2012, Bissenbayeva et al. 2013, Dumitriu et al. 2013). Pelatihan memberikan kesempatan kepada pendamping untuk menambah pengetahuan dan keterampilan mereka sebagai pendamping. Semakin banyak pelatihan yang diikuti oleh pendamping semakin banyak inovasi yang bisa dilakukan oleh pendamping. Pendamping yang lebih banyak mengikuti pelatihan lebih mampu menyesuaikan diri dengan kondisi lingkungan kelompok dampingan. Pendamping dapat memilih perilaku yang berbeda menyesuaikan dengan kondisi kelompok yang berbeda-beda sehingga hubungan dengan kelompok dapat terjalin dengan baik.

Pendamping dengan keterbukaan diri senang menerima masukan dari petani tentang pelatihan apa saja yang diperlukan petani. Pendamping yang sudah banyak memiliki pengalaman pelatihan dapat mengajarkannya langsung pada petani. Pendamping dengan pengalaman pelatihan yang banyak memiliki interaction management yang baik pula karena pendamping yakin mereka berkompeten sebagai seorang pendamping. Pengalaman pendamping melihat berbagai media penyampaian materi dalam pelatihan dapat meningkatkan kreativitas mereka dalam menggunakan media untuk menyampaikan informasi kepada petani.

Pengalaman organisasi pendamping berhubungan nyata dan negatif dengan kemampuan komunikasi tertulis pendamping pada taraf nyata 95 persen. Pengalaman organisasi tidak berhubungan dengan indikator kompetensi komunikasi lainnya. Hasil tersebut berbeda dengan hasil penelitian Kosasih (2015) yang menyatakan bahwa pengalaman organisasi akan meningkatkan keterbukaan komunikasi ke bawah sehingga mendapatkan kesempatan lebih besar dalam menerima informasi.

\section{TINGKAT KEPUASAN PETANI TERHADAP PENDAMPING DAN HUBUNGANNYA DENGAN KOMPETENSI KOMUNIKASI PENDAMPING \\ Tingkat Kepuasan Petani terhadap Pendamping Simantri}

Tabel 6 menyajikan tingkat kepuasan 150 orang petani terhadap 30 orang pendamping Simantri di Kabupaten Klungkung dan Kabupaten Jembrana.

Tabel 6 Tingkat kepuasan petani terhadap pendamping simantri di kabupaten klungkung dan kabupaten jembrana

\begin{tabular}{|c|c|c|c|c|c|c|c|}
\hline \multirow{2}{*}{$\begin{array}{l}\text { Kepuasan petani } \\
\text { terhadap } \\
\text { pendamping (Y2) }\end{array}$} & \multicolumn{3}{|c|}{ Kabupaten klungkung } & \multicolumn{3}{|c|}{ Kabupaten jembrana } & \multirow{2}{*}{$\begin{array}{c}\text { A. Sig. } \\
\text { (2-tailed) }\end{array}$} \\
\hline & $\begin{array}{l}\text { Jumlah } \\
\text { (orang) }\end{array}$ & $(\%)$ & $\begin{array}{c}\text { Mean } \\
\text { rank }\end{array}$ & $\begin{array}{l}\text { Jumlah } \\
\text { (orang) }\end{array}$ & $(\%)$ & $\begin{array}{c}\text { Mean } \\
\text { rank }\end{array}$ & \\
\hline \multicolumn{8}{|l|}{ Reliability (Y2.1) } \\
\hline Rendah & 0 & 0.0 & 13.77 & 0 & 0.0 & 17.23 & 0.281 \\
\hline Sedang & 3 & 20.0 & & 1 & 6.7 & & \\
\hline Tinggi & 12 & 80.0 & & 14 & 93.3 & & \\
\hline
\end{tabular}




\begin{tabular}{|c|c|c|c|c|c|c|c|}
\hline \multicolumn{8}{|c|}{ Responsiveness (Y2.2) } \\
\hline Rendah & 0 & 0.0 & \multirow[t]{3}{*}{13.70} & 0 & 0.0 & \multirow[t]{3}{*}{17.30} & \multirow[t]{3}{*}{0.261} \\
\hline Sedang & 3 & 20.0 & & 0 & 0.0 & & \\
\hline Tinggi & 12 & 80.0 & & 15 & 100.0 & & \\
\hline \multicolumn{8}{|c|}{ Assurance (Y2.3) } \\
\hline Rendah & 0 & 0.0 & \multirow[t]{3}{*}{12.07} & 0 & 0.0 & \multirow[t]{3}{*}{18.93} & \multirow[t]{3}{*}{$0.032^{* *}$} \\
\hline Sedang & 3 & 20.0 & & 0 & 0.0 & & \\
\hline Tinggi & 12 & 80.0 & & 15 & 100.0 & & \\
\hline \multicolumn{8}{|c|}{ Empathy (Y2.4) } \\
\hline Rendah & 0 & 0.0 & \multirow[t]{3}{*}{13.40} & 0 & 0.0 & \multirow[t]{3}{*}{17.60} & \multirow[t]{3}{*}{0.191} \\
\hline Sedang & 3 & 20.0 & & 0 & 0.0 & & \\
\hline Tinggi & 12 & 80.0 & & 15 & 100.0 & & \\
\hline \multicolumn{8}{|c|}{ Tangibles (Y2.5) } \\
\hline Rendah & 0 & 0.0 & \multirow[t]{3}{*}{12.23} & 0 & 0.0 & \multirow[t]{3}{*}{18.77} & \multirow[t]{3}{*}{$0.042^{* *}$} \\
\hline Sedang & 6 & 40.0 & & 1 & 6.7 & & \\
\hline Tinggi & 9 & 60.0 & & 14 & 93.3 & & \\
\hline
\end{tabular}

Sebagian besar pendamping di kedua kabupaten mendapatkan tingkat kepuasan yang tinggi dari para petani. Nilai persentase maupun mean rank menunjukkan bahwa petani di Jembrana memiliki tingkat kepuasan yang lebih tinggi dibandingkan dengan petani di Klungkung pada setiap indikatornya.

Nilai mean rank paling tinggi ada pada indikator assurance yakni 18.93. Hasil analisis komparatif menunjukkan bahwa hanya indikator assurance dan tangibles yang menunjukkan perbedaan signifikan antara Kabupaten Klungkung dan Kabupaten Jembrana pada taraf nyata 95 persen. Petani di Kabupaten Jembrana menilai tinggi pada kemampuan pendamping dalam menumbuhkan rasa percaya diri pada petani, melayani dengan sopan, dan mampu menjawab keluhan petani. Petani di Kabupaten Jembrana memiliki tingkat kepercayaan yang tinggi pada pendamping.

\section{Hubungan Kompetensi Komunikasi Pendamping dengan Kepuasan Petani terhadap Pendamping}

Penelitian ini juga menganalisis korelasi atau hubungan kompetensi komunikasi pendamping dengan kepuasan petani terhadap pendamping (Tabel 7). Analisis korelasi dilakukan antara kompetensi komunikasi pendamping (penilaian petani) dengan kepuasan petani terhadap pendamping.

Hampir seluruh indikator memiliki hubungan nyata dan positif pada taraf kepercayaan 99 persen. Kisaran nilai koefisien korelasi tersebut antara 0.478 0.896. Hasil tersebut sesuai dengan hasil penelitian Madlock (2008) bahwa kompetensi komunikasi supervisor merupakan penentu terbesar dari kepuasan kerja dan kepuasan komunikasi karyawannya. Hasil penelitian Steele dan Plenty (2014) juga menunjukkan bahwa terdapat hubungan positif dan signifikan antara kepuasan komunikasi dan kepuasan kerja karyawan dengan kompetensi komunikasi supervisor berdasarkan penilaian karyawan. Hasil tersebut memperkuat pula pandangan Steele dan Plenty (2014) bahwa hubungan supervisor dan karyawan dalam bentuk dyadic dan interaktif memengaruhi kompetensi komunikasi dan kepuasan komunikasi serta kepuasan kerja.

Tabel 7 Hubungan kompetensi komunikasi pendamping (penilaian petani) dengan kepuasan petani terhadap pendamping 


\begin{tabular}{|c|c|c|c|c|c|}
\hline $\begin{array}{l}\text { Kompetensi komunikasi } \\
\text { pendamping (Y1) }\end{array}$ & $\begin{array}{l}\text { Reliability } \\
\text { (Y2.1) }\end{array}$ & $\begin{array}{l}\text { Responsiveness } \\
\text { (Y2.2) }\end{array}$ & $\begin{array}{l}\text { Assurance } \\
\text { (Y2.3) }\end{array}$ & $\begin{array}{l}\text { Emphaty } \\
\text { (Y2.4) }\end{array}$ & $\begin{array}{l}\text { Tangibles } \\
\text { (Y2.5) }\end{array}$ \\
\hline $\begin{array}{l}\text { Y1.1 Kecepatan merespons } \\
\text { pesan }\end{array}$ & $0.615^{* * * *}$ & $0.560^{* * * *}$ & $0.594^{* * *}$ & $0.570^{* * * *}$ & $0.631^{* * * *}$ \\
\hline Y1.2 Keluwesan berperilaku & $0.674^{* * *}$ & $0.647^{* * *}$ & $0.761^{* * *}$ & $0.675^{* * *}$ & $0.813^{* * *}$ \\
\hline Y1.3 Keterbukaan diri & $0.542^{* * *}$ & $0.589^{* * *}$ & $0.619^{* * *}$ & $0.552^{* * *}$ & $0.592^{* * *}$ \\
\hline $\begin{array}{l}\text { Y1.4 Kemampuan menjalin } \\
\text { relasi }\end{array}$ & $0.496^{* * * *}$ & $0.422^{* *}$ & $0.625^{* * *}$ & $0.549^{* * *}$ & $0.559^{* * *}$ \\
\hline Y1.5 Interaction management & $0.838^{* * *}$ & $0.800^{* * *}$ & $0.896^{* * *}$ & $0.813^{* * *}$ & $0.772^{* * *}$ \\
\hline $\begin{array}{l}\text { Pengetahuan tentang } \\
\text { program }\end{array}$ & $0.628^{* * *}$ & $0.646^{* * *}$ & $0.680^{* * *}$ & $0.590^{* * *}$ & $0.795^{* * *}$ \\
\hline Y1.7 Penyampaian pesan & $0.750^{* * *}$ & $0.688^{* * *}$ & $0.806^{* * *}$ & $0.765^{* * *}$ & $0.744^{* * *}$ \\
\hline Y1.8 Kemampuan memotivasi & $0.674^{* * *}$ & $0.659^{* * *}$ & $0.821^{* * * *}$ & $0.734^{* * *}$ & $0.795^{\text {*** }}$ \\
\hline Y1.9 Komunikasi tertulis & 0.323 & 0.422 & 0.353 & 0.129 & 0.326 \\
\hline Y1.10 Penggunaan media & $0.594^{* * *}$ & $0.556^{* * *}$ & $0.571^{* * *}$ & $0.478^{* * *}$ & $0.646^{* * *}$ \\
\hline Y1.11 Penanganan masalah & $0.436^{* *}$ & $0.428^{* *}$ & $0.498^{* * *}$ & $0.482^{* * *}$ & $0.616^{* * *}$ \\
\hline
\end{tabular}

Tingkat keeratan hubungan paling tinggi atau sangat kuat adalah hubungan antara indikator assurance dan interaction management dengan nilai korelasi 0.896 . Pendamping yang mampu melakukan komunikasi interpersonal dengan baik serta pendamping yang mampu mengatur alur percakapan pada saat rapat ataupun diskusi nonformal bersama kelompok tentu memiliki kesempatan untuk menumbuhkan rasa percaya diri pada petani bahwa kelompok mampu menjalankan program. Petani yang menilai bahwa pendamping mereka memiliki interaction management yang baik adalah petani yang merasakan kepuasan pada kesopanan yang ditunjukkan pendamping serta puas pada kemampuan pendamping dalam menjawab keluhan petani. Pendamping yang memiliki interaction management yang baik lebih dipercaya oleh petani.

Terdapat tiga nilai koefisien korelasi yang menunjukkan adanya hubungan nyata dan positif pada taraf nyata 95 persen, yakni hubungan responsiveness dengan kemampuan pendamping menjalin relasi (0.422), hubungan tangibles dengan kemampuan penanganan masalah (0.436), serta hubungan responsiveness dengan kemampuan penanganan masalah (0.428). Pendamping yang mampu menjalin relasi atau hubungan baik dengan kelompok akan mempermudah pendamping memberikan pelayanan dengan cepat. Pendamping yang ingin menjaga hubungan baik dengan kelompok akan berusaha hadir tepat waktu pada kegiatan-kegiatan Simantri.

Pendamping yang mampu membantu petani menangani masalah harus sigap merespons permintaan petani. Salah satu contohnya adalah ketika salah satu Simantri Jembrana kesulitan melakukan pembuatan instalasi biogas karena air yang mudah merembes ke dalam bangunan (kubang), sehingga penyelesaian pembangunan terlambat. Pendamping kemudian menanyakan solusi kepada BPTP dan PT Biru. Pendamping juga sering menemui Kepala Dinas Pertanian Provinsi Bali agar penanganan masalah lebih cepat terselesaikan. Masalah pun akhirnya dapat terselesaikan.

Pengetahuan terhadap informasi dan materi program berhubungan kuat dengan indikator assurance dengan nilai koefisien korelasi 0.680. Pengetahuan dan keterampilan tidak hanya meningkatkan kepercayaan petani terhadap pendamping, melainkan dapat pula mengakomodir kelompok yang sangat aktif dan "haus" akan pengenalan inovasi pertanian. Keberadaan pendamping bukan hanya membantu administrasi, namun sebagai jembatan penghubung informasi teknologi terbaru kepada petani. Ketika suatu kelompok yang sangat aktif sudah berhasil 
melaksanakan program Simantri, suatu saat mereka akan merasa stagnan karena informasi teknologi terbaru belum mereka terima, saat itulan peran pendamping sangat penting dalam menginformasikan dan mengedukasi petani.

"Sebenarnya kuncinya ada di kelompok kan. Kalau kelompoknya mau aktif, tanpa ada pendamping pun dia bisa jalan. Cuma nanti ke depannya dia akan stuck juga, karena nanti kunci berikutnya adalah pendamping. Kenapa Simantri memerlukan pendamping? Sebenarnya itu dia kuncinya. Di saat dia [kelompok-red] stuck itu, pendamping yang akan memberikan informasi, gitu."

Hasil berbeda terlihat pada indikator kemampuan berkomunikasi secara tertulis yang tidak terdapat hubungan nyata dengan tingkat kepuasan petani terhadap pendamping. Hasil yang menyatakan tidak berhubungan berkaitan dengan belum semua anggota kelompok pernah menerima SMS atau pesan tertulis dari pendamping. SMS biasanya dikirim pendamping kepada ketua kelompok dan apabila anggota perlu mengetahui informasi dalam pesan singkat, maka ketua kelompoklah yang akan menginformasikan kepada anggota baik secara langsung maupun tidak langsung.

\section{SIMPULAN DAN SARAN}

Simpulan penelitian ini adalah (1) kompetensi komunikasi pendamping Simantri secara umum tergolong tinggi, baik pada pendamping Klungkung maupun pendamping Jembrana berdasarkan penilaian sendiri dan penilaian petani. Hasil penilaian berbeda terlihat pada penilaian petani terhadap pendamping Klungkung, yakni pada indikator kemampuan menjalin relasi, kemampuan komunikasi tertulis, dan kemampuan penggunaan media yang dominan pada kategori sedang; (2) tingkat kepuasan petani terhadap pendamping Kabupaten
Klungkung dan Jembrana tergolong tinggi; (3) faktor internal pendamping berhubungan nyata dengan kompetensi komunikasi pendamping, yakni antara umur dengan kemampuan memotivasi, masa kerja dengan kecepatan merespons pesan, tingkat pendidikan formal dengan kecepatan merespons pesan, keluwesan berperilaku, keterbukaan diri, kemampuan menjalin relasi, interaction management, dan kemampuan menyampaikan pesan, tingkat kekosmopolitan dengan kecepatan merespons pesan, serta motivasi dengan kemampuan menyampaikan pesan dan memotivasi. Faktor eksternal pendamping yang berhubungan nyata dan positif dengan kompetensi komunikasi pendamping adalah jumlah pelatihan khususnya dengan indikator keluwesan berperilaku, keterbukaan diri, kemampuan menjalin relasi, interaction management, pengetahuan tentang program, dan kemampuan penggunaan media; dan (4) kompetensi komunikasi pendamping berhubungan nyata dengan kepuasan petani terhadap pendamping. Hampir seluruh indikator memiliki hubungan nyata dan positif pada taraf kepercayaan 99 persen. Hanya indikator kemampuan berkomunikasi secara tertulis yang tidak berhubungan nyata dengan tingkat kepuasan petani terhadap pendamping.

Pendamping sebaiknya lebih aktif mengikuti kegiatan pelatihan yang berkaitan dengan Simantri, baik pelatihan tentang inovasi teknologi pertanian, pemasaran produk Simantri, maupun tentang kompetensi komunikasi. Koordinasi serta proses berbagi ilmu pengetahuan, keterampilan, dan pengalaman antar pendamping perlu ditingkatkan kembali tidak hanya di tingkat kabupaten melainkan di tingkat provinsi.

\section{UCAPAN TERIMA KASIH}


Penulis mengucapkan terima kasih kepada Lembaga Pengelola Dana Pendidikan (LPDP) yang telah memberikan beasiswa penuh kepada penulis selama melanjutkan studi magister di IPB. Penghargaan penulis sampaikan pula kepada Dinas Pertanian Tanaman Pangan Provinsi Bali, BPTP Provinsi Bali, Dinas Pertanian, Perkebunan, dan Kehutanan Kabupaten Klungkung, serta Dinas Pertanian, Perkebunan, dan Peternakan Kabupaten Jembrana, yang telah membantu penulis selama penelitian.

\section{DAFTAR PUSTAKA}

Anugrah, I.S., Sarwoprasodjo, S., Suradisastra, K., dan Purnaningsih, N. 2014. Sistem pertanian terintegrasi - simantri: konsep, pelaksanaan, dan perannya dalam pembangunan pertanian di provinsi bali. Forum Penelitian Agro Ekonomi. Volume 32, Nomor 2, 157176.

Anwas, O.M. 2013. Pengaruh pendidikan formal, pelatihan, dan intensitas pertemuan terhadap kompetensi penyuluh pertanian. Jurnal Pendidikan dan Kebudayaan. Volume 19, Nomor 1, 50-62.

Berlo, D.K. 1960. The Process of Communication an Introduction to Theory and Practice. Michigan: Holt, Rinehart and Winston, Inc.

Bissenbayeva Z, Ubniyazova S, Saktaganov B, Bimagambetova Z, Baytucaeva A. 2013. Communicative competence development model. Procedia. Volume 82, Number 2013, 942-945.

[BPTP Prov Bali] Balai Pengkajian Teknologi Pertanian Provinsi Bali. 2011. Provinsi bali adopsi program prima tani jadi simantri. Dokumen. http://pustaka.litbang.pertanian.go.id /inovasi/k11106-ek64.pdf. Diakses tanggal 25 September 2014.

[BPTP Prov Bali] Balai Pengkajian Teknologi Pertanian Provinsi Bali. 2014. Hasil evaluasi simantri tahun 2009-2013. Denpasar (ID): Balai Pengkajian Teknologi Pertanian Bali.

[Distan Prov Bali] Dinas Pertanian Tanaman Pangan Provinsi Bali. 2013. Petunjuk pelaksanaan petugas pendampingan system pertanian terintegrasi (simantri). Denpasar (ID): Dinas Pertanian Tanaman Pangan Provinsi Bali.

Dumitriu C, Timofti IC, Dumitriu G. 2014. Communicative skill and/or communication competence? Procedia. Volume 141, Number 2014, 489-493.

Heath RL, Bryant J. 2000. Human Communication Theory and Research: Concepts, Contexts, and Challenges. $2^{\text {nd }}$ ed. New Jersey: Lawrence Erlbaum Associates, Inc.

Indra R. 2011. Efektivitas komunikasi kelompok tani dalam mewujudkan keberdayaan petani di kabupaten aceh singkil [tesis]. Bogor (ID): Institut Pertanian Bogor.

Jeffrey, L. dan Brunton, M. 2010. Identifying competence for communication practice: a needs assesment for curriculum development and selection in new zealand. Public Relation Review. Volume 45, Number 1, 61-78.

Kosasih DE. 2015. Komunikasi organisasi dalam pengembangan kinerja pengurus gapoktan pada program penguatan lembaga distribusi pangan masyarakat: kasus pada gapoktan di kabupaten subang dan kabupaten bogor [tesis]. Bogor (ID): Institut Pertanian Bogor.

Madlock PE. 2008. The link between leadership style, communicator competence, and employee 
satisfaction. Journal of Business Communication. Volume 45, Number 1, 61-78.

Mangkuprawira S. 2010. Strategi peningkatan kapasitas modal sosial dan kualitas sumber daya manusia pendamping pembangunan pertanian. Forum Penelitian Agro Ekonomi. Volume 28, Nomor 1, 1934.

Payne HJ. 2005. Reconceptualizing social skills in organitions: exploring the relationship between communication competence, job performance, and supervisory roles. Journal of Leadership and Organizational Studies (Sage Publication). Volume 11, Nomor 2, 63-77.

Steele GA, Plenty D. 2014. Supervisorsubordinate communication competence and job and communication satisfaction. International Journal of Business Communication (Sage Publication). 1-25.

Suardi ID. 2015. Strategi komunikasi program pembangunan pertanian: kasus program simantri di provinsi bali. [disertasi]. Denpasar (ID): Universitas Udayana.

Susanto D. 2010. Strategi peningkatan kapasitas modal sosial dan kualitas sumberdaya manusia pendamping pengembangan masyarakat. Jurnal Komunikasi Pembangunan. Volume 8 , Nomor 1, 77-89.

Susilowati M. 2012. Peningkatan kompetensi komunikasi interpersonal dan kinerja pre ops pilot selama masa percobaan di pt. X dengan memberikan pelatihan komunikasi interpersonal yang efektif. [tesis]. Depok (ID): Universitas Indonesia.

Widodo S. 2010. Kompetensi penyuluh pertanian terampil berdasarkan pendidikan: kasus di kabupaten garut, magelang, dan tuban [tesis]. Bogor (ID): Institut Pertanian Bogor. 